\title{
A LABILE SERUM FACTOR CLOTTING DEFECT: ITS DEMON- STRATION BY THE THROMBOPLASTIN GENERATION TEST AND ITS CLINICAL SIGNIFICANCE*
}

\author{
By WILLIAM E. CONNOR, $\dagger$ E. D. WARNER AND JOHN R. CARTER
}

(From the Departments of Internal Medicine and Pathology, State University of Iowa, College of Medicine, Iowa City, Iowa)

(Submitted for publication August 3, 1960; accepted August 19, 1960)

The thromboplastin generation test, originally described by Biggs and Douglas (2), has proved to be a valuable tool in the study and diagnosis of hemorrhagic disease. Several problems have arisen from its use, however. These have centered about the preparation of the reagents for the test and the implications of an abnormal test result. This test, which measures the rate of formation and the amount of plasma thromboplastin, may be performed with platelet factor 3 supplied by either a platelet suspension or an emulsion of phosphatides from soybeans or brain. In the routine performance of the test we have used a soybean phosphatide.

Early in the course of our studies with the thromboplastin generation test, we occasionally found a serum factor deficiency different from deficiencies of PTC (factor IX) or Stuart factor (factor X). This labile serum factor defect was not evident in fresh serum but developed as the serum was aged from 3 to 24 hours. The abnormality was noted in some patients with undiagnosed bleeding whose other coagulation tests were normal. Patients with liver disease, patients with polycythemia vera, and newborn infants usually had this defect. It was sometimes found, combined with other defects, in patients receiving coumarin drugs. It occured in a few "normal" control subjects. Such defective thromboplastin generation could be corrected readily by the use of any one of the following in the test system: serum aged 3 to 24 hours from most normal human subjects; serum aged for only 1 or 2 hours

\footnotetext{
* Presented in part at the Forty-Fourth Annual Meeting of the Federation of American Societies for Experimental Biology, Chicago, Ill., April 13, 1960 (1). Supported by research grants from the American and Iowa Heart Associations, and from the National Institutes of Health.

$\dagger$ This work was performed during the tenure of an American Heart Association Research Fellowship.
}

from the patient under study; aged sera from patients with PTC (factor IX) deficiency; sera deficient in Stuart factor (factor X); and by the use of platelets instead of soybean phosphatide as the source of platelet factor 3 . Some characteristics of this labile serum factor suggest a similarity to the factor in serum described by Duckert, Flückiger, Matter and Koller (3) and Spaet and Kropatkin (4).

The studies to be reported will illustrate and define this labile serum factor and will point out its possible significance in patients.

\section{METHODS}

All blood was drawn by the two-syringe technic. Normal oxalated plasma was obtained by adding $7 \mathrm{ml}$ of whole blood to $1 \mathrm{ml}$ of 1.85 per cent potassium oxalate solution and centrifuging the mixture 10 minutes at 4,000 $\mathrm{rpm}$ and $4^{\circ} \mathrm{C}$. Adsorbed plasma was provided by mixing $1 \mathrm{ml}$ of oxalated plasma with $100 \mathrm{mg}$ barium sulfate for 30 minutes with a magnetic stirrer and then centrifuging. Such plasma did not clot after the addition of brain thromboplastin and calcium chloride, and its prothrombin content by the two-stage method was always less than 5 per cent and usually unmeasurable. Barium sulfate-adsorbed serum was prepared similarly. For the "aged serum" reagent, blood was allowed to clot and incubated for 1 hour at $37^{\circ} \mathrm{C}$. The serum was then removed and aged additionally at $37^{\circ} \mathrm{C}$ for variable periods of time. Most studies were performed with reagents which had not been frozen previously. We did demonstrate, however, that sera which in the fresh state had the labile serum factor defect continued to manifest the same defect when stored at $-30^{\circ} \mathrm{C}$ for as long as 2 weeks before being thawed and tested. The age of the serum was designated as the number of hours of incubation after venipuncture. The soybean phosphatide ${ }^{1}$ concentration was 0.1 per cent in saline. A platelet suspension was prepared from platelet-rich plasma obtained from blood centrifuged at $700 \mathrm{rpm}$ in an angle centrifuge at $4^{\circ} \mathrm{C}$. Platelets were then separated by centrifugation of the platelet-rich plasma at $4,000 \mathrm{rpm}$. The resulting

\footnotetext{
${ }^{1}$ Gliddex “O” (Glidden Co.).
} 
"platelet" clump was broken up and washed 3 times with saline. After the final resuspension in a volume of saline equal to the volume of the plasma from which they were derived, the platelets were frozen and thawed 3 times prior to use to insure adequate disruption. Thrombin at a strength of $100 \mathrm{U}$ per $\mathrm{ml}$ was prepared from bovine thrombin. ${ }^{2}$ It was diluted with normal saline to give various concentrations. This thrombin-saline solution was employed as the diluent for the serum or barium sulfate-adsorbed plasma whenever thrombin was to be added to the thromboplastin generation test.

The thromboplastin generation test (TGT) (5) was performed by incubating $0.3 \mathrm{ml} \mathrm{BaSO}_{4}$-adsorbed plasma (diluted $1 / 5$ with saline), $0.3 \mathrm{ml}$ aged serum (diluted $1 / 5$ with saline), $0.3 \mathrm{ml}$ of 0.1 per cent soybean phosphatide, and $0.1 \mathrm{ml}$ of $0.015 \mathrm{M} \mathrm{CaCl}_{2}$. The adsorbed plasma and the aged serum were used immediately after dilution. Plasma having a normal concentration of prothrombin and fibrinogen was used for the substrate or indicator plasma. When thromboplastin generation was normal, a fibrin clot always formed in the incubation tube at about the time maximal thromboplastin developed. No clot formed in the incubation tube when thromboplastin generation did not occur.

Corrections of abnormal test results were made as follows. The serum, which was to be tested for corrective potential, was supplied to the system in place of $0.15 \mathrm{ml}$ of the patient's diluted serum, so that the total serum reagent volume was maintained at the usual $0.3 \mathrm{ml}$ and consisted of $0.15 \mathrm{ml}$ of the patient's diluted serum and $0.15 \mathrm{ml}$ of the diluted "corrective" serum. Corrective sera included normal serum, the patient's serum aged for shorter periods of time, PTC (factor IX) deficient serum, and Stuart factor (factor X) deficient serum. ${ }^{3}$ In some tests the platelet suspension was used to replace the soybean phosphatide as the source of platelet factor 3 . $\mathrm{BaSO}_{4}$-adsorbed plasma from normal subjects was employed in place of the patient's adsorbed plasma. The corrective effect of thrombin was tested by supplying it to the thromboplastin generation test as the thrombinsaline diluent for the serum or $\mathrm{BaSO}_{4}$-adsorbed plasma. More highly purified bovine thrombin and prothrombin ${ }^{4}$ were added in the same way for use in TGT correction.

To express thromboplastin generation capacity in a numerical value related to percentage of normal, the area above the thromboplastin generation curve was compared with that obtained with the blood of normal controls. The clotting times of the substrate plasma were plotted against the incubation time of the thromboplastin generation mixture. The area encompassed by the curve with the limits of a 60 second clotting time and a 2 to 12 minute incubation period was then measured with a planimeter. This area is dependent upon both the amount

\footnotetext{
2 Thrombin, Topical, Parke-Davis \& Co.

${ }^{3}$ Courtesy of Dr. John B. Graham, University of North Carolina.

4 Courtesy of Dr. Walter H. Seegers, Wayne State University (thrombin, lot 591222; prothrombin, lot 600203).
}

of thromboplastin generated and the rate of its formation. A test result below 75 per cent was considered definitely abnormal. Most of the patients with the labile serum factor defect had values from 0 to 20 per cent.

Thrombin and prothrombin were measured by twostage methods $(6,7)$ and antithrombin by the method of Seegers, Miller, Andrews and Murphy (8).

Patients described in this study included several groups: those with unexplained clinical bleeding referred for diagnostic study; patients with liver disease; patients with polycythemia vera; newborn infants; and patients receiving coumarin-type anticoagulants. Individuals from the medical and nursing hospital staff provided normal controls.

\section{RESULTS}

Characterization of labile serum factor. Figures 1,2 , and 3 illustrate the labile serum factor defect. This particular patient had an abnormal thromboplastin generation test when his serum was aged 24 hours at $37^{\circ} \mathrm{C}$ (Figure 1). Substrate plasma clotting times were all above 60 seconds, and no clot formed in the incubation tube. Serum aged only 3 hours resulted in abnormal thromboplastin generation also, although the deficiency was less. Normal serum aged 24 hours completely corrected the defect. When the patient's serum was aged only 1.5 hours, a normal test resulted.

The substitution of platelets for soybean phosphatide as the source of platelet factor 3 led to

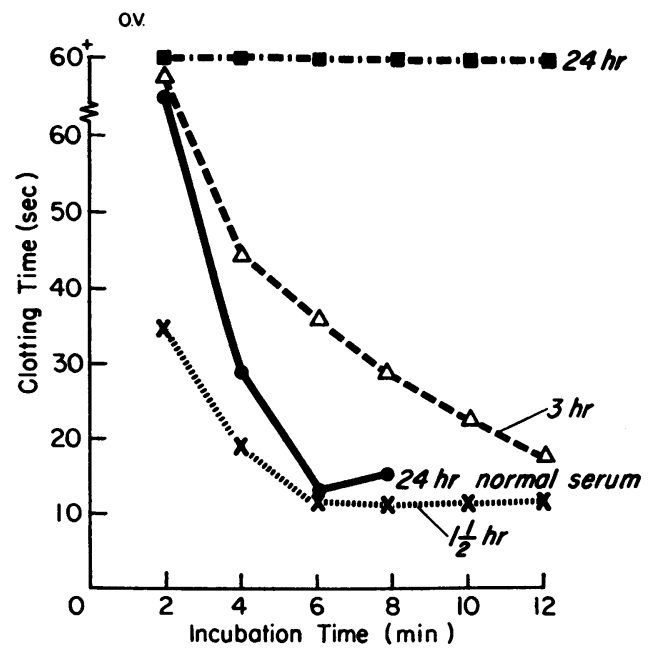

Fig. 1. Thromboplastin generation in the labile SERUM FACTOR DEFICIENCY. The incubation times of the thromboplastin generation mixture are shown on the horizontal axis and the clotting times of the substrate plasma are plotted on the vertical axis. The appended "number of hours" refers to the aging of the patient's serum unless otherwise indicated. 


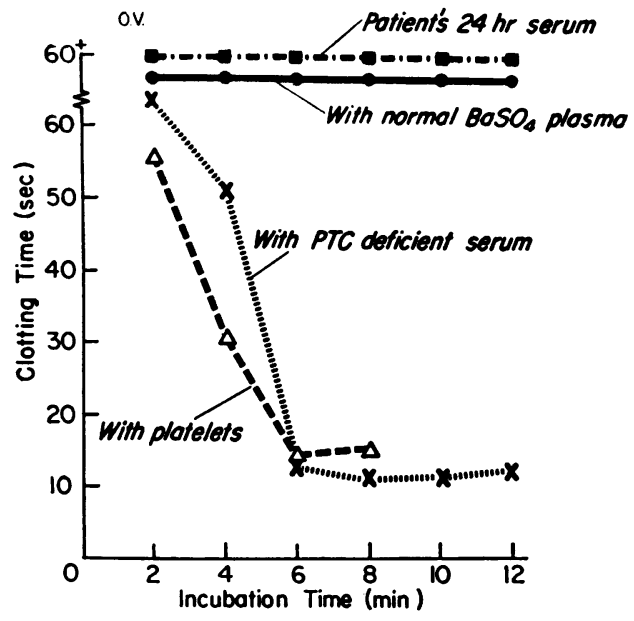

Fig. 2. Correction of the labile Serum factor defect By Platelets and PTC deficient SERUM.

normal thromboplastin generation even though the patient's 24-hour serum was used (Figure 2). This occurred with platelets either from the patient or from a normal subject. Serum deficient in PTC (factor IX) effected complete correction of the patient's 24-hour serum. $\mathrm{BaSO}_{4}$-adsorbed normal plasma was not corrective. Stuart (factor $\mathrm{X}$ ) deficient serum similarly restored normal thromboplastin generation (Figure 3). Normal serum adsorbed with barium sulfate did not correct the defect. These results suggested that the labile serum factor differed from PTC, PTA and the Stuart factor, was more labile on aging than these factors, and was adsorbed by barium sulfate.

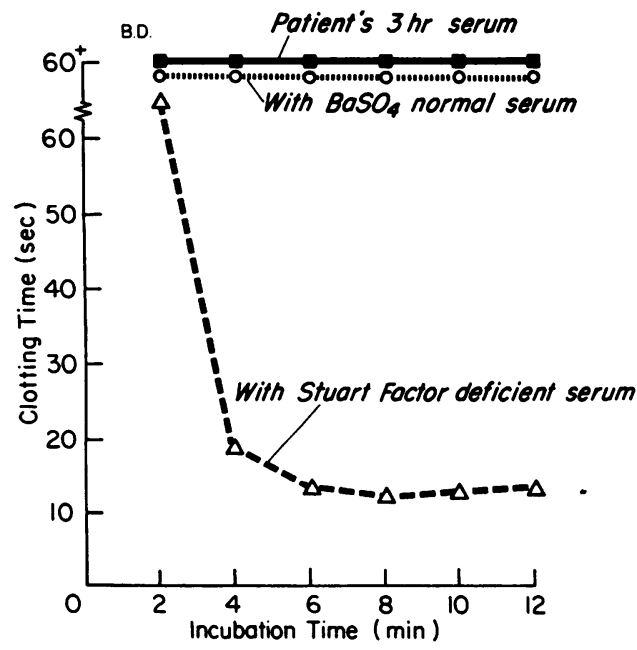

Fig. 3. Correction of the labile SERUM factor defect BY Stuart Deficient SERUM.
The role of thrombin. The formation of a clot in the incubation tube in the normal thromboplastin generation test has already been mentioned. This clot appeared about the time that thromboplastin became maximal in the mixture, as indicated by a minimal clotting time of 10 to 12 seconds of the substrate test plasma. Thus, it seemed likely that the formation of thrombin and the generation of a potent thromboplastin were linked closely in the thromboplastin generation test. This suggested the possibility that normal thromboplastin generation was dependent upon the catalytic effect of a trace of thrombin in the aged serum. Perhaps the aging of the serum from some individuals resulted in the complete inactivation of the traces of thrombin.

The effects of various amounts of thrombin upon thromboplastin generation in this labile serum defect are shown in Figure 4. Even trace amounts of thrombin, as little as $0.024 \mathrm{U}$ added to the incubation tube, corrected the labile serum defect. Ten to 20 times this amount of thrombin greatly accelerated thromboplastin generation; the usual lag period was eliminated. The addition of this minute amount of thrombin did not result in thromboplastin generation unless soybean phosphatide, aged serum and $\mathrm{BaSO}_{4}$-adsorbed plasma were all present in the mixture. The minimal

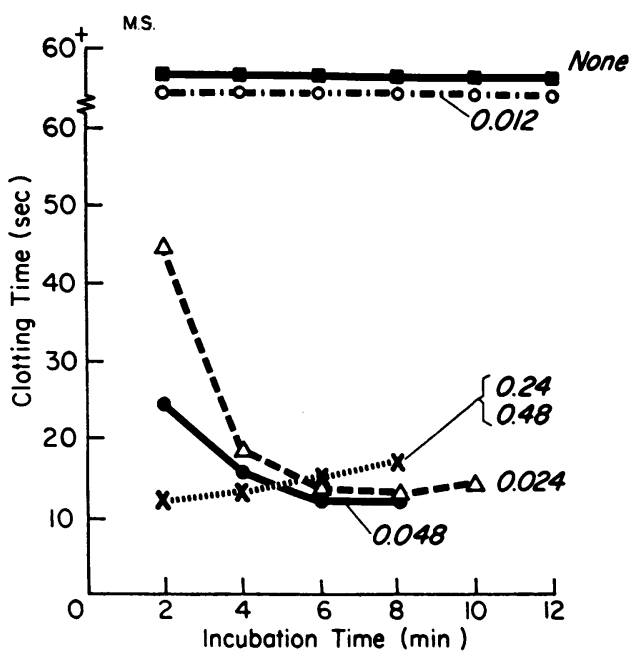

Fig. 4. THE efFects of Different CONCENTRATIONS OF THROMBIN ON THROMBOPLASTIN GENERATION IN THE LABILE SERUM FACTOR DEFICIENCY. The patient's 3 hour old serum, normal plasma, and soybean phosphatide were used in all tests. The units of thrombin added are appended to each curve. 
amount of thrombin, usually $0.024 \mathrm{U}$, which was required to correct the labile serum defect, was much too small to be detected hy ordinary methods; c.g., it would not clot tibrinogen or plasnia.

In most of these studies the thrombin was added to the incubation tube as a thrombin-saline diluent of the serum reagent. If it was added as a part of the saline diluent for the barium sulfate-adsorbed plasma, a similarly normal thromboplastin generation test resulted. As might be expected, however, thrombin added to the substrate plasma did not correct an abnormal thromboplastin generation test resulting from the labile serum factor defect. It was essential that the thrombin be present in the incubation mixture during the period of thromboplastin generation. This amount of thrombin, $0.024 \mathrm{U}$, had no or little effect upon the greatly impaired thromboplastin generation found in patients with hemophilia (factor VIII deficiency) and with PTC (factor IX) deficiency. Twenty-two patients with hemophilia and eight patients with PTC deficiency were so studied.

Because the thrombin reagent used (Thrombin, Topical) might be contaminated with other substances, more highly purified thrombin was tested in the thromboplastin generation system having this labile serum factor defect. The corrective property of this purified thrombin preparation was

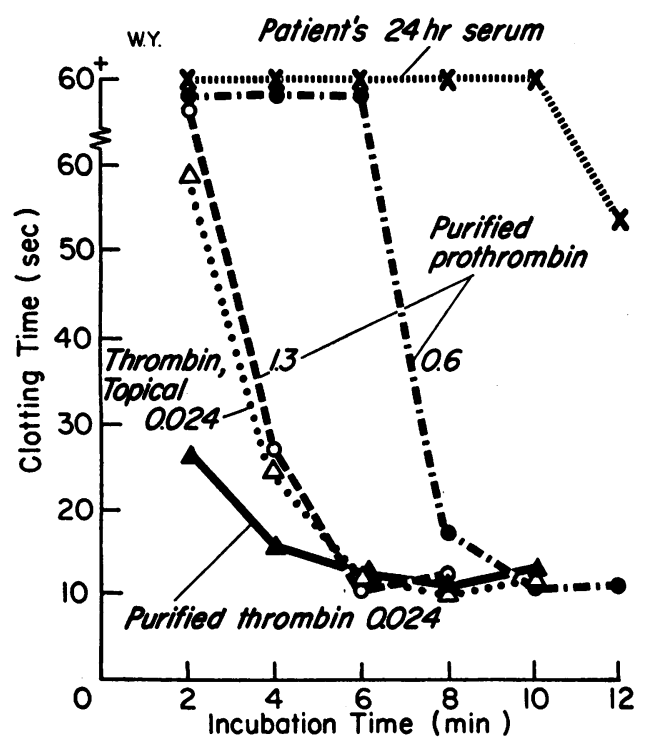

Fig. 5. EFFects of pUrified thrombin, Thrombin, TOPICAL, AND PURIFIED PROTHROMBIN ON THE THROMBOPLASTIN GENERATION IN THE LABILE SERUM FACTOR DEFICIENCY. Units per milliliter indicated for each curve.

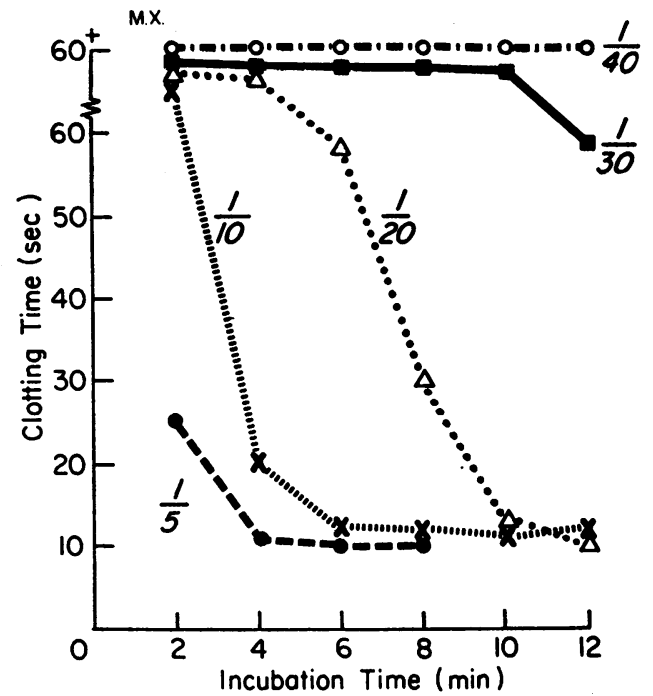

Fig. 6. The Labile SERUM FACTOR DEFECT IN THROMBOPLASTIN GENERATION WITH THE DILUTION OF NORMAL SERUM. The appropriate dilution of normal serum is appended to each thromboplastin generation curve.

also compared with that of purified prothrombin, as shown in Figure 5. The purified thrombin corrected the defect in a manner similar to the correction obtained with Thrombin, Topical of the same strength. Purified prothrombin was also corrective but only when amounts many times larger were used. The addition of $1.3 \mathrm{U}$ of prothrombin was necessary to produce the same effect obtained with $0.024 \mathrm{U}$ of thrombin, either as purified thrombin or as Thrombin, Topical.

Quantitative aspects of the labile serum factor. The labile serum factor defect has developed spontaneously with the aging of some sera from 3 to 24 hours at $37^{\circ} \mathrm{C}$. A similar defect also could be produced in normal serum by dilution of a given sample. As shown in Figure 6, the yield of thromboplastin progressively declined with successive serum dilutions with saline until, at a $1 / 40$ dilution, none was produced. The critical dilution range of five normal sera so tested was between $1 / 20$ and $1 / 40$. With thromboplastin generation thus rendered abnormal by serum dilution, complete correction was obtained by the use of any one of the following (Figure 7):0.024 $\mathrm{U}$ of thrombin; PTC (Factor IX) deficient serum; Stuart factor (factor $\mathrm{X}$ ) deficient serum; and the use of platelets in place of soybean phosphatide. It seemed evident that this labile serum factor could be diluted beyond effective concentration 


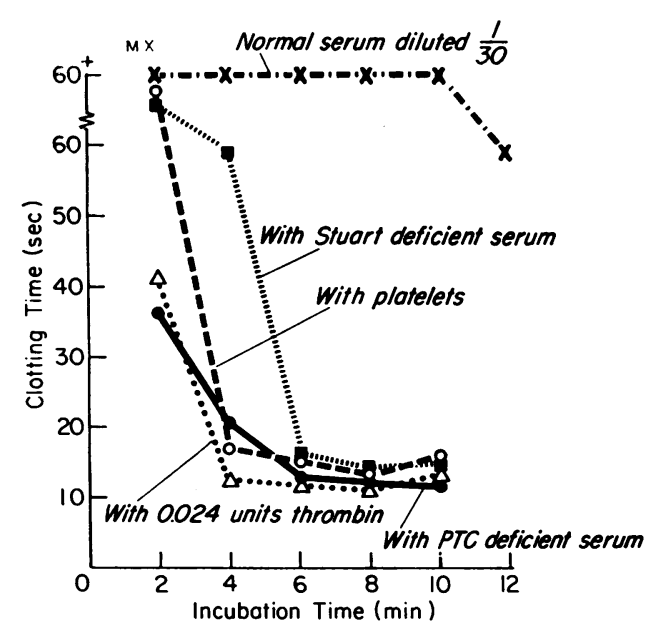

Fig. 7. The CORReCtion of THE LABILE SERUM FaCtor DEFECT INDUCED IN DILUTED NORMAL SERUM. Normal serum was diluted $1 / 30$ for use in all tests.

in normal aged serum without the loss of effective amounts of PTC and the Stuart factor.

In addition, the ability of normal serum to correct the labile serum deficiency in thromboplastin generation was lost progressively with dilution. Table I-A shows the corrective effects of normal serum in varied dilutions on the labile serum defect. The normal serum was added to the serum defective in the labile serum factor in a ratio of $1: 1$ and the thromboplastin generation test performed. In this instance, also, there was a critical dilution which failed to correct the defect-i.e., at $1 / 20$.

TABLE I

Corrections of the labile serum factor defect by various dilutions of normal serum and PTC deficient serum*

\begin{tabular}{|c|c|c|c|}
\hline \multicolumn{3}{|c|}{ Serum component $0.3 \mathrm{ml}$} & \multirow{2}{*}{$\begin{array}{l}\text { Thrombo- } \\
\text { plastin } \\
\text { generation }\end{array}$} \\
\hline Dilution & Amount & Amount & \\
\hline & $m l$ & $m l$ & $\begin{array}{c}\% \text { of } \\
\text { normal }\end{array}$ \\
\hline
\end{tabular}

A. Normal serum

$\begin{array}{cr}\text { Patient's serum } & \\ 0.30 & 90 \\ 0.15 & 104 \\ 0.15 & 78 \\ 0.15 & 53 \\ 0.15 & 29\end{array}$

B. PTC deficient serum

$\begin{array}{ll}1 / 30 & 0.15 \\ 1 / 100 & 0.15 \\ 1 / 1,000 & 0.15\end{array}$

$\begin{array}{rr}0.30 & 30 \\ 0.15 & 111 \\ 0.15 & 84 \\ 0.15 & 0\end{array}$

* Normal barium sulfate-adsorbed plasma and normal substrate plasma were used. The patient's serum was diluted 1/5 for all tests. Saline was the diluent.
PTC deficient serum in serial dilutions was supplied to a test system containing serum with the lahile factor defect (Tahle I-B). It was ohserved that considerably lesser amounts of $\Gamma \mathrm{TC}$ deficient serum than of normal serum corrected the abnormal thromboplastin generation of this patient's serum. This result implied that, whatever the corrective factor might be, it was present in higher concentration in the PTC deficient serum than in normal serum. Since PTC deficient serum has poor prothrombin conversion, prothrombin is one substance in higher concentration in PTC deficient serum than in normal serum when both are aged for 3 hours. Thrombin may also be involved, since in serum with only partial prothrombin conversion thrombin continues to form slowly until all of the prothrombin is converted.

The incubation of thrombin and platelets individually with serum. Serum with the labile factor defect had the capacity to nullify the corrective effects of 0.024 to $0.048 \mathrm{U}$ of thrombin during the course of an hour's incubation of this serum with thrombin (Table II). This occurred with either Thrombin, Topical, or purified thrombin. The incubation of thrombin, alone and diluted as for use in the TGT for 1 hour at $37^{\circ} \mathrm{C}$, did not de-

TABLE II

Incubation of thrombin and platelets individually with serum *

\begin{tabular}{|c|c|}
\hline & $\begin{array}{l}\text { Thrombo- } \\
\text { plastin } \\
\text { generation }\end{array}$ \\
\hline $\begin{array}{l}\text { A. Test systems: serum alone and } \\
\text { serum plus thrombin }\end{array}$ & $\begin{array}{c}\% \text { of } \\
\text { normal }\end{array}$ \\
\hline Serum alone & 0 \\
\hline $\begin{array}{l}\text { Serum }+0.048 \mathrm{U} \text { of thrombin } \\
\text { No incubation } \\
\text { Incubation for } 1 \mathrm{hr}\end{array}$ & $\begin{array}{r}117 \\
0\end{array}$ \\
\hline Serum $+0.048 \mathrm{U}$ of thrombin $\dagger$ & 100 \\
\hline $\begin{array}{l}\text { B. Test systems: serum alone and } \\
\text { serum plus platelets }\end{array}$ & \\
\hline Serum alone & 0 \\
\hline $\begin{array}{l}\text { Serum plus platelets } \\
\text { No incubation } \\
\text { Incubation for } 1 \mathrm{hr}\end{array}$ & $\begin{array}{l}111 \\
113\end{array}$ \\
\hline
\end{tabular}

* The serum and thrombin, and serum and platelets were incubated 1 hour at $37^{\circ} \mathrm{C}$ before use in the thromboplastin generation test. The serum used had been shown deficient in the labile serum factor after being aged 24 hours at $37^{\circ} \mathrm{C}$

$\dagger$ Thrombin previously incubated 1 hour at $37^{\circ} \mathrm{C}$. 
TABLE III

Effect of heat on the labile factor in normal and PTC deficient serum*

\begin{tabular}{|c|c|c|c|c|}
\hline \multicolumn{3}{|c|}{ Serum reagent } & \multirow{3}{*}{$\begin{array}{l}\text { Thrombin } \\
\text { addition }\end{array}$} & \multirow{3}{*}{$\begin{array}{l}\text { Thrombo } \\
\text { plastin } \\
\text { generation }\end{array}$} \\
\hline \multirow{2}{*}{$\begin{array}{l}\text { Patient's } \\
\text { serum } \\
\text { (labile } \\
\text { serum } \\
\text { factor } \\
\text { defect) } \\
\text { Amount }\end{array}$} & \multicolumn{2}{|c|}{ Normal serum } & & \\
\hline & Preparation & Amount & & \\
\hline$m l$ & $\min /{ }^{\circ} \mathrm{C}$ & $m l$ & $U$ & $\begin{array}{c}\% \text { of } \\
\text { normal }\end{array}$ \\
\hline 0.30 & & & & 0 \\
\hline 0.15 & Usual & 0.15 & & 100 \\
\hline 0.15 & $15 / 50$ & 0.15 & & 57 \\
\hline 0.15 & $30 / 50$ & 0.15 & & 44 \\
\hline 0.15 & $60 / 50$ & 0.15 & & 28 \\
\hline 0.15 & $5 / 56$ & 0.15 & & 0 \\
\hline 0.15 & $15 / 50$ & 0.15 & 0.024 & 102 \\
\hline 0.15 & $60 / 50$ & 0.15 & 0.024 & 94 \\
\hline 0.15 & $5 / 56$ & 0.15 & 0.024 & 54 \\
\hline \multicolumn{5}{|c|}{ PTC deficient serum } \\
\hline 0.15 & $60 / 50$ & 0.15 & & 100 \\
\hline 0.15 & $5 / 56$ & 0.15 & & 20 \\
\hline
\end{tabular}

* Normal serum was heated for different periods of time at various temperatures. It was then used to correct the labile serum factor defect. PTC deficient serum was similarly tested. The other reagents in the thromboplastin generation test were as previously described. The patient's serum and the normal serum were diluted $1 / 5$ with saline before use in the quantities indicated.

stroy its ability to correct the labile serum defect.

Prothrombin $(1.3 \mathrm{U})$ then was incubated with the defective serum. Such a mixture retained its original ability to provide normal thromboplastin generation. Of course, this amount of prothrombin was very large as compared with the amount of thrombin used.

The corrective action of platelets on the TGT was not destroyed after an hour's incubation of the serum and platelets together. The antithrombin of the serum deficient in the labile factor was similar to that of normal serum.

Heat stability of the labile serum factor. The heat stability of this factor in normal and PTC deficient serum is given in Table III. These sera tended to lose their ability to correct the labile serum defect with progressive heating. For example, normal serum heated 15 minutes at $50^{\circ} \mathrm{C}$ only partially corrected the abnormal thromboplastin generation of the labile serum defect. Further heating at $50^{\circ} \mathrm{C}$ provided additional losses of the labile factor in normal serum. The heating of the normal serum to $56^{\circ} \mathrm{C}$ for 5 minutes led to complete loss of activity. The addition of
$0.024 \mathrm{U}$ of thrombin completely restored the capacity of the normal serum heated to $50^{\circ} \mathrm{C}$ to generate thromboplastin. Thrombin did not correct completely normal serum heated to $56^{\circ} \mathrm{C}$. Heating was less effective in destroying the corrective capacity of PTC deficient serum, perhaps because of the larger amounts of residual prothrombin and thrombin present in this serum.

Patients and subjects with the labile serum factor defect. With all of these individuals, the defect was manifest in serum aged for 3 hours. Thirty-three patients with different types of clinical bleeding of unknown cause had abnormal thromboplastin generation because of the labile serum factor defect. These included patients with gastrointestinal bleeding, nosebleeds, easy bruising, operative and postoperative bleeding, and subdural hematomas. In none of these patients were there found local lesions or other hematological and coagulative abnormalities to explain the bleeding. The labile serum factor defect continued to be present when the same patients were restudied on subsequent occasions. Some patients had required transfusions. Four others, however, had had abdominal surgery performed without excessive operative or postoperative bleeding.

Many of these patients had a family history of bleeding. The labile serum factor defect was found in two sisters who bruised easily and bled excessively after dental extractions. It was demonstrated in a mother and daughter, both with a history of bleeding. It was found in the son and two grandsons of a man who had died of unexplained massive gastrointestinal bleeding.

The labile serum factor defect was present in 10 of 13 patients with polycythemia vera. In addition to elevated hemoglobin, erythrocyte and hematocrit values, most of these patients had elevated platelet counts. Their thromboplastin generation defect was severe and typically was corrected by serum aged 1 or 2 hours, thrombin 0.024 $\mathrm{U}, \mathrm{PTC}$ deficient serum, or platelets from normal subjects.

Ten other patients with abnormal thromboplastin generation due to deficient labile serum factor included three patients with hereditary hemorrhagic telangiectasia, two with thrombasthenia and five with myelofibrosis.

Umbilical cord blood was obtained from new- 
born infants. The sera obtained from these blood specimens were used in the thromboplastin generation test. The barium sulfate-adsorbed plasma and the substrate plasma used were from normal adults. Nine of the ten newborn sera tested had abnormal thromboplastin generation, characteristic of the labile serum factor defect. In these, the test results ranged from 0 to 74 per cent, with five sera producing no thromboplastin generation.

One hundred two studies were performed in 75 "normal" adult subjects. In only six of these was the thromboplastin generation abnormal when the serum was aged 3 hours. In each instance the abnormality was caused by the typical labile serum defect which tended to be moderate rather than severe. The test results were $71,70,60,43$, 41 and 20 per cent for these six tests.

Labile serum factor defect in liver disease. The thromboplastin generation test was abnormal in 33 of 47 patients with hepatic cirrhosis. With serum aged for 3 hours, thromboplastin generation ranged from 0 to 74 per cent. In 28 of these patients the serum defect fitted well into the labile serum factor classification in that it was corrected by the addition of $0.024 \mathrm{U}$ of thrombin, by the patient's serum aged only 1 or 2 hours, by normal aged serum, usually by the use of platelets, by PTC deficient serum, or by Stuart deficient serum (this latter attempted in only one instance). Eleven of these patients were studied subsequently on 20 occasions and continued to demonstrate the labile serum factor defect. Three patients did not have the defect when restudied later but had had clinical improvement of the liver disease. The five other patients with alnormal thromboplastin generation had multiple defects which included Stuart factor and PTC as well as the labile serum factor. Their tests were only partially corrected by serum aged 1 hour, by platelets, by $0.024 \mathrm{U}$ of thrombin, or by PTC deficient serum.

Most of the patients with cirrhosis had associated reduced prothrombin and factor VII concentrations; some had, in addition, increased fibrinolytic activity. The 14 other patients with normal thromboplastin generation had low prothrombin and factor VII concentrations.

The labile sermu factor defect and coumarin druys. Thromboplastin generation in patients receiving coumarin therapy was almost always abnormal. This abnormality, as is described else-

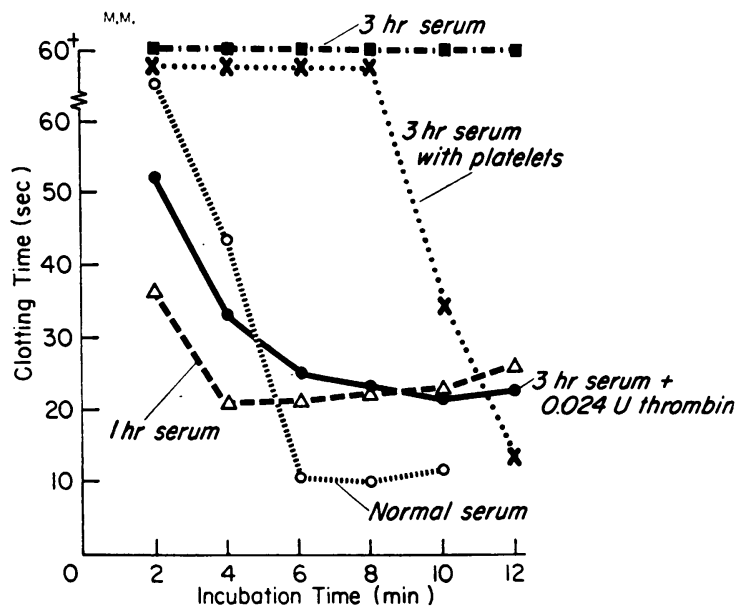

Fig. 8. The labile Serum factor defect in a patient receiving Dicumarol. His prothrombin time by the onestage test was 22.5 seconds (control 13.6 seconds).

where, was caused usually by Stuart factor and PTC deficiencies (9). In some patients, however, the labile serum factor defect contributed somewhat to the thromboplastin deficiency. Figure 8 illustrates this point. Serum aged only 1 hour, the addition of thrombin, or the use of platelets all corrected partially the very abnormal thromboplastin generation caused by defects in the patient's 3-hour serum.

Cross correction studies. On many occasions serum from one patient with the labile serum factor defect was used in an attempt to correct the abnormal thromboplastin generation test of another patient with a similarly identified defect. In no instance was the slightest correction obtained. A failure of correction also resulted when sera from the patients with liver disease or from those receiving coumarin drugs were so tested.

\section{DISCUSSION}

The "labile serum factor" deficiency in thromboplastin generation encountered in these patients had some of the attributes of a PTC deficiency. Normal serum provided complete correction; the failure of normal barium sulfate-adsorbed plasma to correct the alsnormal thromboplastin generation test ruled out deficiencies of factor VIII, factor $V$, P'TA and the "glass" factor. When it was found that PTC deficient serum completely corrected the defect, however, it was clear that a PTC deficiency was not the explanation. In a similar 
manner, the possibility of a Stuart factor deficiency was ruled out. The next question arose as to what other known serum factor could be defective.

Serum, of course, contains initially many of the substances present in plasma and, in addition, the substances formed in the process of clotting. In 1904 Bordet and Gengou called attention to the clot-promoting activity of serum (10). They believed that this activity in serum might be thrombin or a derivative. Serum from normal subjects aged for 3 hours at $37^{\circ} \mathrm{C}$ does not exhibit thrombic activity, however, as indicated by an ability to clot fibrinogen or plasma. It might still contain traces of thrombin which might catalyze thromboplastin generation and other reactions.

Others have shown that serum contains clotpromoting activity apparently different from thrombin $(11,12)$; DeVries, Alexander and Goldstein have termed such activity SPCA or serum prothrombin conversion accelerator (11). It is now most commonly recognized as factor VII. Ware and Seegers have also stressed the presence of serum accelerator globulin (factor VI) in serum (13). PTC (factor IX), the Stuart factor (factor X) and PTA are other well recognized components of aged serum.

Factor VII has been considered unnecessary for the thromboplastin generation test (14). It is also much more stable than the "labile serum factor," since it resists heating to $56^{\circ} \mathrm{C}$ for $30 \mathrm{~min}$ utes (14). The plasma from patients with the "labile serum factor" defect had a normal factor VII level. Such information suggests that the labile serum factor was probably not factor VII.

In 1955 Duckert, Flückiger, Matter and Koller described a serum factor, necessary for thromboplastin formation, which was absent in sera from Dicumarol-treated patients, the newborn, and patients with hepatitis and cirrhosis (3). Their serum factor was adsorbed by barium sulfate and disappeared from normal sera in a few hours to a few days when stored at room temperature. The thromboplastin generation test in the patients with this defect became much worse when they used a brain extract as a source of platelet factor 3 instead of platelets. Recently Koller, of this same group, has indicated that the serum factor which they described was primarily the Stuart factor (factor X) (15). Spaet and Kropatkin procluced a thromboplastin generation deficiency in normal sera aged in the refrigerator for 1 week or longer (4). It was distinguished from Stuart factor or prothrombin deficiencies but was thought to be closely related to prothrombin or a prothrombin derivative. This defect was also found in liver disease (16). Abnormal thromboplastin generation from a serum defect resulted when normal serum was incubated with thorium (17). The thorium-induced deficiency was corrected by PTC (factor IX) and PTA deficient sera but not by refrigerator-aged serum or Dicumarol serum.

The labile serum factor which we have described appears somewhat similar to the factors originally described by Duckert and co-workers and by Spaet and Kropatkin $(3,4)$. Our results have indicated that a deficiency of this factor was produced readily in sera from certain patients by aging 3 to 24 hours at $37^{\circ} \mathrm{C}$. It was destroyed in normal sera by incubation at $50^{\circ} \mathrm{C}$. A defect of this factor could be produced quantitatively in normal serum by serial dilutions with saline. The factor was essential for normal thromboplastin generation with the use of soybean phosphatide as the source of platelet factor 3 .

A trace amount of purified thrombin $(0.024 \mathrm{U})$ corrected the labile serum factor defect. This amount, insufficient to clot fibrinogen or plasma, was adequate to restore normal thromboplastin generation to sera with the defect. Thrombin in this small quantity did not effect normal thromboplastin generation in PTC or in AHG deficiencies. Purified prothrombin, in much larger and measurable amounts, also restored normal thromboplastin generation.

Serum with the labile factor defect had the capacity to nullify the usual corrective effect of thrombin if the thrombin and serum were incubated together prior to use in the TGT. Such serum destroyed or inactivated this small amount of thrombin. The corrective effect of platelets was not destroyed by incubation with the serum.

Platelets are known to possess a number of factors with blood clotting activity (14). Of these, platelet factor 3 is the only one known to be essential for thromboplastin generation. Our results suggest that platelets also contain another essential factor which is also present in normal aged serum. Desforges and Bigelow have shown that platelets previously inculated with thrombin have greatly enhanced thromboplastic activity 
(18). Perhaps such activity is attributable to adsorption of thrombin to platelets. The ability of platelets to correct the labile serum factor defect may then depend upon their adsorption of a trace of thrombin or like substance.

These studies of the labile serum factor defect suggest that thrombin in minute amounts must be present for normal thromboplastin generation. That thrombin has such a catalytic role in the TGT is not surprising in view of its profound effect upon so many other blood clotting tests. For example, thrombin activates antihemophilic globulin (19); it converts accelerator globulin into an active form (13); it aids in the conversion of prothrombin to thrombin (20); it "labilizes" platelets (21). We have no information about the mechanism through which thrombin may exert its effect in thromboplastin generation.

Biggs, Douglas, and Macfarlane found that a low concentration of thrombin, too small to clot plasma but which would clot fibrinogen in about 150 seconds, accelerated normal thromboplastin generation (22). Miale and Wilson suggested that the thrombic activity observed to develop in the incubation tube of the TGT might have importance in thromboplastin formation (23). They found that the addition of $0.25 \mathrm{U}$ of thrombin accelerated normal thromboplastin formation and reduced the usual lag period. This amount was much greater than the $0.024 \mathrm{U}$ needed to correct the labile serum defect.

We do not know that the labile serum factor defect has any relationship to hemorrhagic disease. Since it develops only with the aging of serum, perhaps it is only a laboratory curiosity. Yet this defect was encountered in many patients with clinical bleeding otherwise unexplained and in some other patients with other known coagulation defects. The in vitro ability of a serum to destroy this labile serum factor or traces of thrombin, as the case may be, may bear a relationship to such an in vivo phenomenon as a bleeding tendency.

The thromboplastin generation test has a growing use in clinical laboratories for the diagnosis of hemorrhagic disease. Should the platelet factor 3 reagent be supplied as a soybean or brain phosphatide instead of as a platelet suspension, it is clear that an abnormal TGT will result from time to time from the labile serum factor defect. Such an abnormal TGT must be interpreted properly after the performance of detailed corrective studies. Only thus can the over-diagnosis of a disease like PTC (factor IX) deficiency be avoided.

\section{SUMMARY AND CONCLUSIONS}

A labile serum factor necessary for thromboplastin generation has been described. A deficiency of this factor appears in the serum of some patients which has been aged 3 to 24 hours. The defect manifests itself when soybean phosphatide is used as the source of platelet factor 3 in the thromboplastin generation test. Studies to date suggest that the labile factor is a trace of thrombin and that, in sera showing the defect, such traces of thrombin are destroyed in a few hours. If so, this is simply another illustration of the importance of thrombin as a catalyst for clotting reactions.

We have found the labile serum factor defect in many patients with otherwise unexplained bleeding of clinical significance. In addition, it has consistently been detected in the newborn and in patients with liver disease, with polycythemia vera, and after coumarin drugs. It was rarely found in normal adult individuals whose serum was aged for 3 hours at $37^{\circ} \mathrm{C}$. Whether or not this serum abnormality has real importance in the production of hemorrhagic disease remains to be established.

The labile serum factor defect can be confused readily with deficiencies of other serum factors, especially with PTC (factor IX). Such confusion seems especially likely in the quantitative studies with the thromboplastin generation test since this factor, probably thrombin, can readily be diluted beyond effective concentration in aged normal serum.

\section{REFERENCES}

1. Warner, E. D., Connor, W. E., and Carter, J. R. A labile serum factor needed for thromboplastin generation. Fed. Proc. 1960, 19, 63.

2. Biggs, R., and Douglas, A. S. The thromboplastin generation test. J. clin. Path. 1953, 6, 23.

3. Duckert, F., Flückiger, P., Matter, M., and Koller, F. Clotting factor X. Physiologic and physicochemical properties. Proc. Soc. exp. Biol. (N. Y.) $1955,90,17$.

4. Spaet, T. H., and Kropathin, M. Factor X phenomenon. J. appl. Physiol. 1959, 14, 581.

5. Connor, W. E., and Carter, J. R. Influence of soybean phosphatide on blood coagulation and its use 
in the thromboplastin generation test. Proc. Soc. exp. Biol. (N.Y.) 1958, 97, 38.

6. Johnson, J. F., and Seegers, W. H. Preparation, purification and assay of thrombin in The Coagulation of Blood-Methods of Study, L. M. Tocantins, Ed. New York, Grune and Stratton, 1955, pp. $120-123$.

7. Ware, A. G., and Seegers, W. H. Two-stage procedure for the quantitative determination of prothrombin concentration. Amer. J. clin. Path. 1949, $19,471$.

8. Seegers, W. H., Miller, K. D., Andrews, E. B., and Murphy, R. C. Fundamental interactions and effect of storage, ether, adsorbents and blood clotting on plasma antithrombin activity. Amer. J. Physiol. 1952, 169, 700.

9. Hoak, J. C., Connor, W. E., Warner, E. D., and Carter, J. R. The anti-thrombotic properties of coumarin drugs. Presented at the Annual Meeting of the American College of Physicians, April 6, 1960, San Francisco. Ann. intern. Med. To be published.

10 Bordet, J., and Gengou, O. Recherches sur la coagulation du sang; sur le pouvoir cogulant du serum. Ann. Inst. Pasteur 1904, 18, 98.

11. DeVries, A., Alexander, B., and Goldstein, R. A factor in serum which accelerates the conversion of prothrombin to thrombin. I. Its determination and some physiologic and biochemical properties. Blood 1949, 4, 247.

12. Jacox, R. F., and Bays, R. P. Studies of the thrombin effect of fresh serum. Proc. Soc. exp. Biol. (N.Y.) 1949, 70, 587.

13. Ware, A. G., and Seegers, W. H. Serum ac-globulin: Formation from plasma ac-globulin; role in blood coagulation; partial purification; properties; and quantitative determination. Amer. J. Physiol. 1948, 152, 567.

14. Macfarlane, R. G. Blood coagulation with particular reference to the early stages. Physiol. Rev. 1956, 36, 479.

15. Koller, F. What is the present status of Factor $\mathrm{X}$ ? in Hemophilia and Other Hemorrhagic States, K. M. Brinkhous and P. de Nicola, Eds. Chapel Hill, University of North Carolina Press, 1959, pp. 231-239.

16. Rabiner, S. F., and Spaet, T. H. Thromboplastin generation as a test of liver function. Amer. J. med. Sci. 1959, 238, 280.

17. Alexander, B., and Colman, R. Evidence for a new serum thromboplastic factor in New Blood Clotting Factors, I. S. Wright, F. Koller and F. Streuli, Eds. Thromb. Diath. haemor. 1960, suppl. to vol. IV, pp. 66-85.

18. Desforges, J. F., and Bigelow, F. S. An action of thrombin on platelets in accelerating clotting. Blood 1954, 9, 153.

19. Penick, G. D. Some factors that influence utilization of antihemophilic activity during clotting. Proc. Soc. exp. Biol. (N.Y.) 1957, 96, 277.

20. Fukutake, K., Cho, M. H., and Seegers, W. H. Activation of prothrombin with thrombin. Amer. J. Physiol. 1958, 194, 280.

21. Stefanini, M. Autocatalytic formation of thrombin in blood coagulation. Acta med. scand. 1951, 140, 290.

22. Biggs, R., Douglas, A. S., and Macfarlane, R. G. The formation of thromboplastin in human blood. J. Physiol. (Lond.) 1953, 119, 89.

23. Miale, J. B., and Wilson, M. P. Studies on the thromboplastin generation test. II. Basic mechanism and theoretrical aspects. Amer. J. clin. Path. 1956, 26, 984. 